PPPL-3021

PPPL-3021

UC-420,421,426

REAL-TIME BORONIZATION IN PBX-M USING EROSION OF SOLID BORONIZED TARGETS

BY

H.W. KUGEL, J. TIMBERLAKE, R. BELL, ET AL.

NOVEMBER 1994
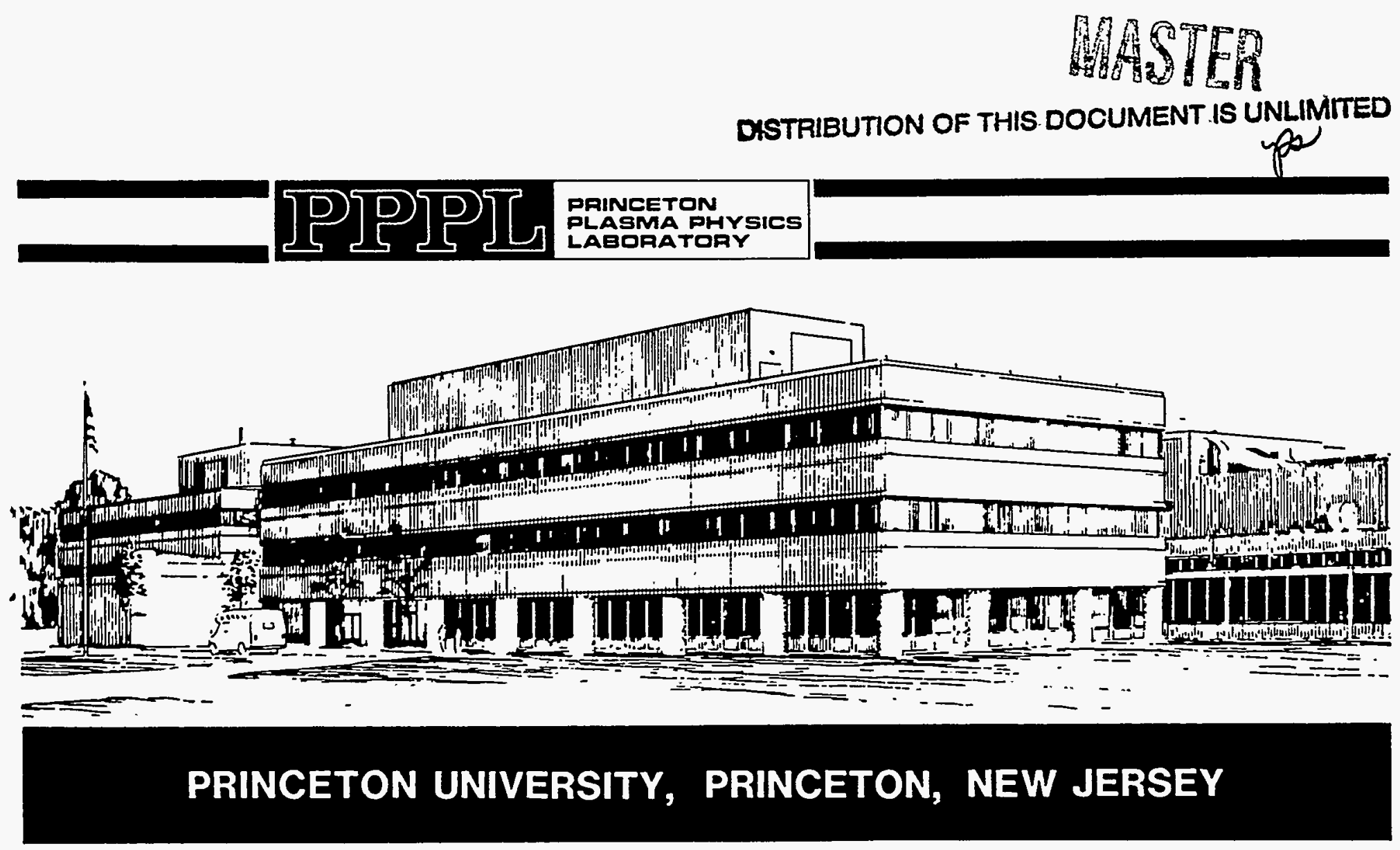


\section{NOTICE}

This report was prepared as an account of work sponsored by an agency of the United States Government. Neither the United States Government nor any agency thereof, nor any of their employees, makes any warranty, express or implied, or assumes any legal liability or responsibility for the accuracy, completeness, or usefulness of any information, apparatus, product, or process disclosed, or represents that its use would not infringe privately owned rights. Reference herein to any specific commercial produce, process, or service by trade name, trademark, manufacturer, or otherwise, does not necessarily constitute or imply its endorsement, recommendation, or favoring by the United States Government or any agency thereof. The views and opinions of authors expressed herein do not necessarily state or reflect those of the United States Government or any agency thereof.

\section{NOTICE}

This report has been reproduced from the best available copy.

Available in paper copy and microfiche.

Number of pages in this report: 14

DOE and DOE contractors can obtain copies of this report from:

Office of Scientific and Technical Information

P.O. Box 62

Oak Ridge, TN 37831;

(615) $576-8401$.

This report is publicly available from the:

National Technical Information Service

Department of Commerce

5285 Port Royal Road

Springfield, Virginia 22161

(703) $487-4650$ 


\section{DISCLAIMER}

Portions of this document may be illegible in electronic image products. Images are produced from the best available original document. 


\title{
Real-Time Boronization in PBX-M Using Erosion of Solid Boronized Targets
}

\author{
H. W. Kugel, J. Timberlake, R. Bell, A. England1), Y. Hirooka2), R. Isler1), \\ B. LeBlanc, M. Okabayashi, S. Paul, W. Tighe, A. Post-Zwicker1) \\ Princeton Plasma Physics Laboratory, Princeton University, P. O. Box 451, \\ Princeton, NJ 08543, USA \\ 1) ORNL, Fusion Energy Division, Bldg. 9201-2, P. O. Box 2009, \\ Oak Ridge, TN 38731, USA \\ 2) University of California at Los Angeles, IPFR, 139-44 Engr. IV Bldg., \\ Los Angeles, CA 90024, USA
}

\begin{abstract}
Thirty one real-time boronizations were applied to PBX-M using the plasma erosion of solid target probes. More than $17 \mathrm{~g}$ of boron were deposited in PBX-M using this technique. The probes were positioned at the edge plasma to optimize vaporization and minimize spallation. Auger depth profile analysis of poloidal and toroidal deposition sample coupon arrays indicate that boron was transported by the plasma around the torus and deep into the divertors. During discharges with continuous real-time boronization, low- $Z$ and high- $Z$ impurities decreased rapidly as plasma surfaces were covered during the first 20-30 discharges. After boronization, a short-term improvement in plasma conditions persisted prior to significant boron erosion from plasma surfaces, and a longer term, but less significant improvement persisted as boron farther from the edge continued gettering. Real-time solid target boronization has been found to be very effective for accelerating conditioning to new regimes and maintaining high performance plasma conditions.
\end{abstract}




\section{Introduction}

Real-time solid target boronization (STB) is the deposition of boron on machine surfaces by vaporization from boronized target probes inserted into edge plasmas either during special discharges for boronization or during typical experimental discharges [1-3]. Boron deposited by STB is an effective getter for typical plasma impurities and its deposition results in a significant improvement in tokamak plasma properties [1, 2]. STB is useful for maintaining boron coated surfaces in high duty cycle and long pulse discharges during which thin pre-applied boron films are eroded quickly from near-plasma surfaces. STB does not introduce undesirable hydrogen species into machines being prepared for deuterium operation and it does not require a bakeable vessel. STB is environmentally benign, intrinsically safe, non-toxic, inexpensive to install and maintain, and convenient to apply. These advantages were demonstrated in initial experiments [1-2], and motivated the first extensive application of STB in PBX-M. In this paper, we report on the PBX-M STB procedure, STB performance during plasma operations, and the relative simplicity and effectiveness of STB as a routine, real-time impurity control technique.

\section{Experimental Geometry}

Fig. 1 shows a partial schematic elevation view of PBX-M showing passive plate stabilization system and other hardware. The circled numbers identify deposition sample locations discussed below. The STB probe was inserted on the midplane into the edge plasma.

The initial boronization of PBX-M was performed with a mushroom-shaped STB probe which consisted of a $10.7 \%$ boronized 2-dimensional carbon-carbon composite containing $3.6 \mathrm{~g}$ of boron in a $\mathrm{B}_{4} \mathrm{C}$ binder [4]. The improvement in PBX-M plasma performance [2] was similar to that observed on TdeV [1]. These results motivated the development of procedures for routine, real-time STB of PBX-M. Recent STB depositions have used rectangular graphite-felt probes consisting of about $85 \%$ boronized graphite-felt composites containing about $30 \mathrm{~g}$ of 40 micron diameter boron particles loosely-held in the felt matrix [2]. These probes are characterized by high boron yields per probe ( 1 to $8 \mathrm{~g}$ ), high boron-to-carbon fraction ( $\leq 86 \%$ boron), high thermal shock resistance, low thermal conductivity $(<2000$ that 
of graphite) for rapid heating in edge plasmas, and good electrical conductivity for finding probe-plasma edge location.

The STB probe was mounted on a carbon-carbon composite and attached to the probe drive mechanism. The probe assembly was electrically isolated from the vessel and inserted into the edge plasma via a bellows mechanism at one toroidal location. Only one probe was inserted into PBX-M per STB application.

\section{STB Procedure, Performance, and Results}

The procedure used for STB on PBX-M evolved from the experience accrued during 31 STB applications. Typically, STB depositions were performed as part of the conditioning process in preparation for achieving suitable plasma conditions. At other times, for special experiments, STB was performed during the actual experimental discharges. In particular, boronizations were performed to accelerate achieving good vacuum conditions after vessel openings to atmosphere, to recover from degraded plasma conditions after disruptions, to aid plasma initiation and reduce loop voltage, and to achieve high performance plasma conditions for normal double-null diverted plasma operations with Neutral Beam Injection (NBI) and active profile control using Lower Hybrid Current Drive (LHCD) and Ion Bernstein Wave (IBW) heating.

The preparations for an STB application were begun by establishing indented, bean-shaped, $250 \mathrm{kA}$, diverted deuterium plasmas with strike points that were swept during the discharge across the inner passive plates and into the divertors. This was done so as to aid the spreading of boron over the passive plate surfaces and the transport of boron into deep divertor regions. These plasmas were either ohmic or NBI heated depending on the circumstances. Ohmic plasmas, for example, were convenient for STB while awaiting the daily preparation of NBI systems.

The initial mushroom probe (BP-1) was used for 2 applications and 3 graphite-felt probes $(B P-2,-3,-4)$ for 29 applications. Fig. 2 shows a photograph of STB graphite felt probe BP-3 after exposure to PBX-M plasmas during 16 boronizations of varying duration and vaporization rate. In Fig. 2, the ions were incident from the right (co-direction). The total boron loss was $8.3 \mathrm{~g}$. The final probe tip was about $50 \%$ shorter than before exposure.

Each STB application consisted of inserting a target probe into the edge

plasma and vaporizing boron using either ohmic or NBI heated discharges for 1-2 hours per application (20-30 discharges lasting about $800 \mathrm{~ms}$ ). The number of 
available applications per probe varied with the boron content and the vaporization rate. Using the difference between the initial and final probe weights to quantify the boron loss from the probes [2], it was estimated that more than $17 \mathrm{~g}$ of boron were deposited in PBX-M using the STB technique.

New probes were moved through the torus port and positioned inside the vessel at the outer wall for several hours to allow slow heating and residual outgassing. Using calibrated probe measurements, previously used probes were promptly positioned about $1 \mathrm{~cm}$ outside the plasma edge and then incremented inward about $0.25 \mathrm{~cm}$ per discharge. The probe edge position was optimized using a plasma TV camera, probe floating potential, and UV spectroscopy.

During the probe insertion process, the incandescence of the probe tip was monitored by a plasma TV system and recorded with a VCR for inspection during non-plasma operations. This probe-viewing diagnostic was considered essential for achieving controlled steady vaporization and avoiding arcing or spallation from fast heating due to edge conditions or to the depth of insertion. The integrated visible and near-infrared signal intensity detected by this system exhibited a rise time characteristic of an approximately constant applied power density and an exponential-like decay.

The use of a new probe permitted the probe drive indicator to accurately indicate the probe position relative to the plasma. As the probe tip was slowly eroded during many STB applications, however, the probe drive indicator gave a less accurate indication of true probe position relative to the edge plasma. The effective probe radial edge position could be monitored using the probe floating potential. Fig. 3 shows the floating potential of an STB probe against apparent position given by the probe drive indicator. As a probe slowly eroded, during many boronizations, the floating potential could be used to give a useful indication of the relative probe position in the edge plasma, e.g., in Fig. 3, typically in the range from $R=190.0$ to $192.0 \mathrm{~cm}$ depending on the plasma conditions. The principal indicator, however, of the appropriateness of the probe position and STB progress was the spectroscopic observation of boron and impurity emissions.

During STB, UV spectroscopic measurements of changes in the boron, carbon, oxygen, and metallic impurity emission intensities were used to monitor the effectiveness of the boron deposition rate and the resulting plasma conditions. For example, as the BIII intensity increased, the OVI intensity decreased by about a factor of 3.5 or more, before STB was stopped and normal operations were 
resumed. Typically about 12 light impurity and metal UV emission intensity waveforms were observed during STB to monitor deposition and cleanup progress.

After deuterium discharges, the possible volatilization of boron compounds was investigated via mass analysis of residual gases in the vessel and exiting via the pumping system. Mass number $A=47$ identified as $\mathrm{D}_{2} \mathrm{BO}_{2}$, was the only gaseous boron compound observed. Mass number $A=29$ appeared to be DBO but this is not yet confirmed. Additional work is in progress to quantify the amount of boron exiting the vessel via the pumping system.

In order to measure the distribution of boron applied by STB from one probe location, thin stainless steel sample coupons were attached to the passive plates and other machine surfaces, in poloidal arrays at different toroidal locations and subjected to 29 STB applications. The 24 poloidal locations of the impurity deposition samples are indicated in Fig. 1 by the circled numbers. A similar 24 sample poloidal array was located at each of four toroidal locations, about every 90 degrees, for a total of 96 deposition samples. Auger electron spectroscopy analysis depth profiling was performed on these samples [5]. Some Auger electron spectra exhibited boron energy shifts indicative of oxide, boride, and possibly the carbide compounds. Fig. 4 shows the results for the boron poloidal and toroidal thickness distributions. At the STB probe position (62 degrees toroidally), the boron depositions on the outer midplane passive plates are about 30-40 Angstroms and mostly greater than 10 Angstroms at the other poloidal locations farther from the midplane. At the other toroidal locations, the boron deposition thicknesses are in the range from about 1 to 5 Angstroms. This is also seen, in particular, at the poloidal sample array at 247 degrees, which is toroidally opposite the STB probe, and for which the line-of-sight to the probe is occulted by the center column of the vessel. Similarly, some poloidal locations at toroidal 157 and 337 degrees, within line-of-sight of the STB probe, also tended to receive thicker depositions. These results indicate that there was extensive boron toroidal distribution due to plasma transport, and extensive boron deposition near the probe due to line-of-sight evaporation. The poloidal positions No. 4 and No. 20 are deep in the upper and lower divertors, respectively, and exhibited about the same deposition thicknesses as nearby poloidal locations. This is attributed to the effect of sweeping the plasma strike points during the discharge across the near divertor region and then deep into the divertors, and possibly some scattering from the main plasma, although this region is not within line-of-sight of the main plasma. Additional work now in progress is needed for a detailed understanding of variations in the deposited film thickness, 
boron inventory, erosion, co-deposition, and redeposition during extensive continuous real-time STB.

\section{Discussion and Summary}

During discharges with continuous real-time boronization, boron was transported by the plasma around the torus and into the divertors, and low- $Z$ and high-Z impurities decreased rapidly as plasma surfaces were covered during the first 20-30 discharges, and more slowly thereafter. During discharges after boronization, a short-term improvement in plasma conditions persisted prior to significant boron erosion from plasma surfaces, and a longer term, but less significant, improvement persisted as boron farther from the edge continued gettering [2]. About 3-4 applications per week seemed adequate for PBX-M $800 \mathrm{~ms}$ discharges at duty cycles of about $4 \mathrm{~min}$. After STB, boron UV emission data indicated that disruptions can redistribute boron. The clean plasma conditions achieved with STB reduced loop voltage during LHCD experiments and allowed the exploration of a new IBW regime of enhanced core confinement ( $\mathrm{CH}$-mode) achieved after using STB [6].

Continuous real-time solid target boronization has been found to be very effective for accelerating conditioning to new regimes and maintaining good plasma conditions. This technique also is applicable to radiative mantle experiments and to the deposition of other coatings such as $\mathrm{Be}, \mathrm{Li}$, and $\mathrm{Si}$.

\section{Acknowledgment}

We wish to acknowledge the helpful contributions of G. Gettelfinger, J. Semler, E. Thorsland, and the PBX-M Technical Staff. The PBX-M project is supported by US DoE Contract No. DE-AC02-76-CHO-3073. 


\section{References}

[1] Y. Hirooka, et al., Nuc. Fus. 32 (1992) 2029.

[2] H. W. Kugel, et al., Fus. Techn. 25 (1994) 377.

[3] D. J. Den Hartog, et al., J. Nucl. Mater.; 200 (1993) 177. Refer also to D. J. Den Hartog et al., in this conference.

[4] Y. Hirooka and R.W. Conn, IPFR, University of California, Los Angeles, Report UCLA PPG \#1478, March 1993, and in Atomic and Plasma-Material Interaction Processes in Controlled Fusion, ed. R. Janev, IAEA, (1993), Vienna.

[5] R. L. Moore, Evans East Inc., 666 Plainsboro Road, Suite 1236, Plainsboro, NJ 08536.

[6] B. LeBlanc, et al., submitted for publication in Physics of Plasmas. 


\section{Figure Captions}

Fig. 1. Partial schematic diagram of PBX-M showing passive plate system and internal hardware. The circled numbers indicate deposition sample locations.

Fig. 2. Photograph of an STB graphite-felt probe after 16 boronizations.

Fig. 3. Floating potential of an STB probe against apparent position given by the probe drive indicator.

Fig. 4. Boron poloidal and toroidal deposition thickness distributions. STB probe was at 62 degrees. 


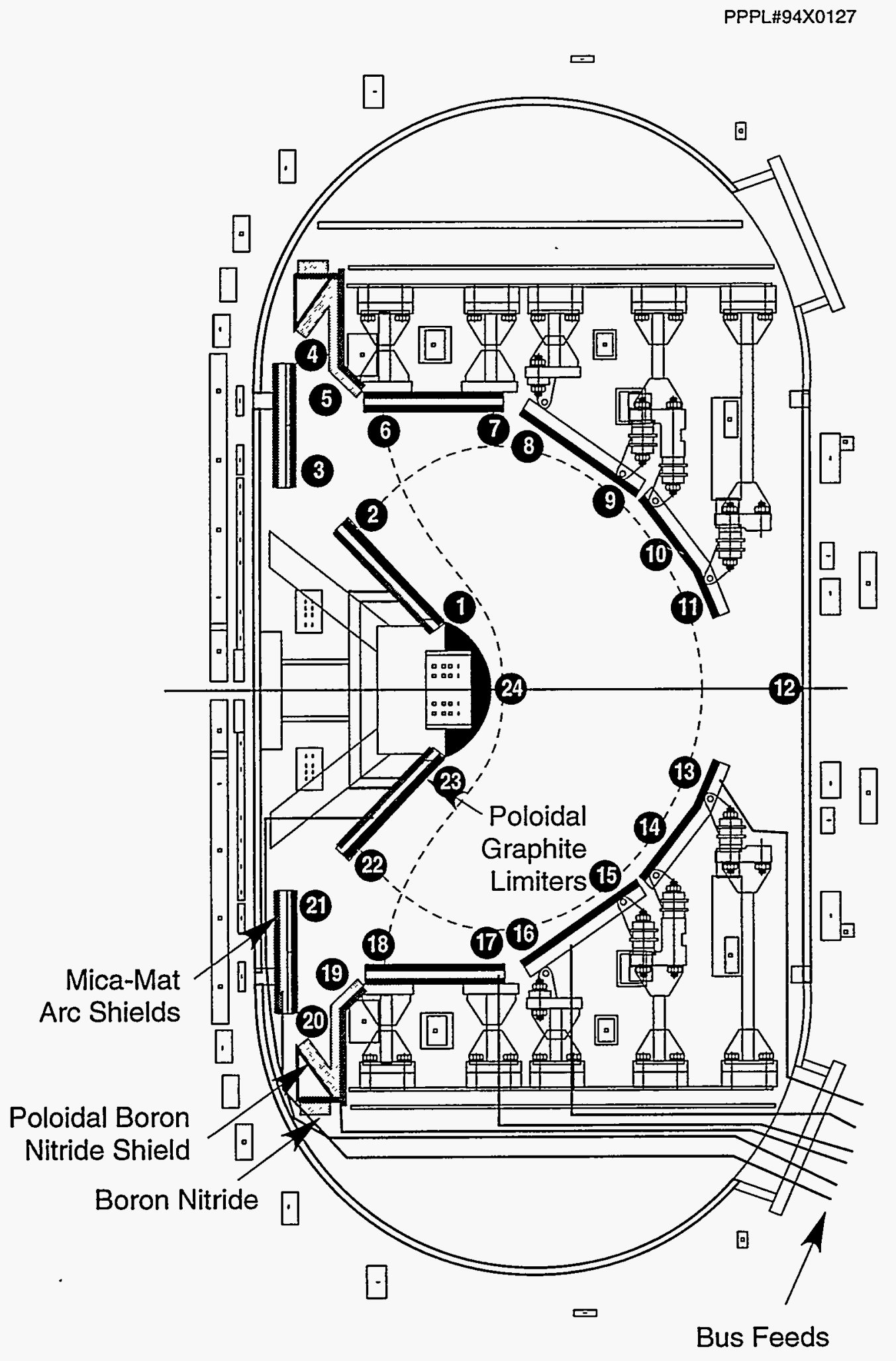

Fig. i 


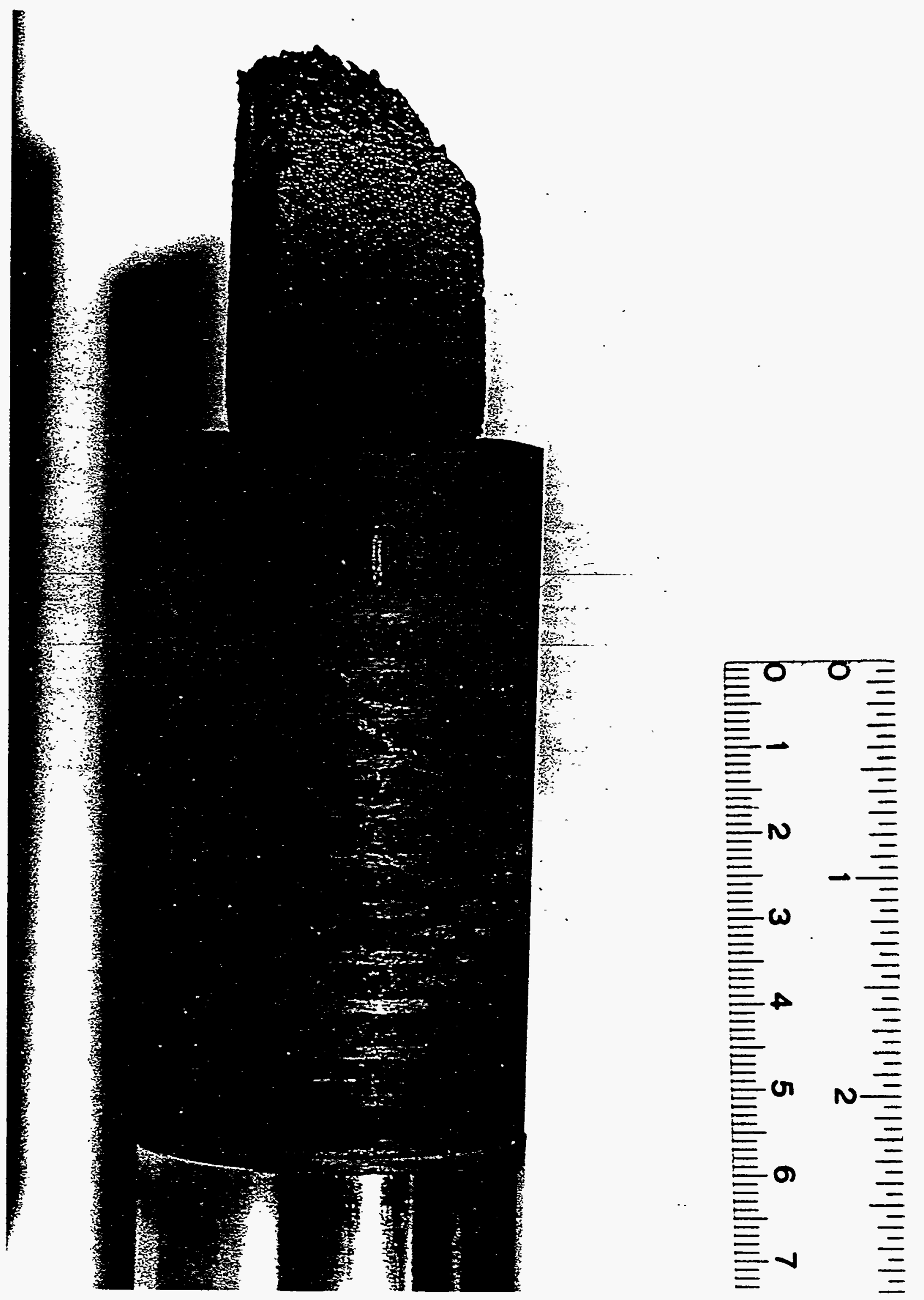

Fig, 2 


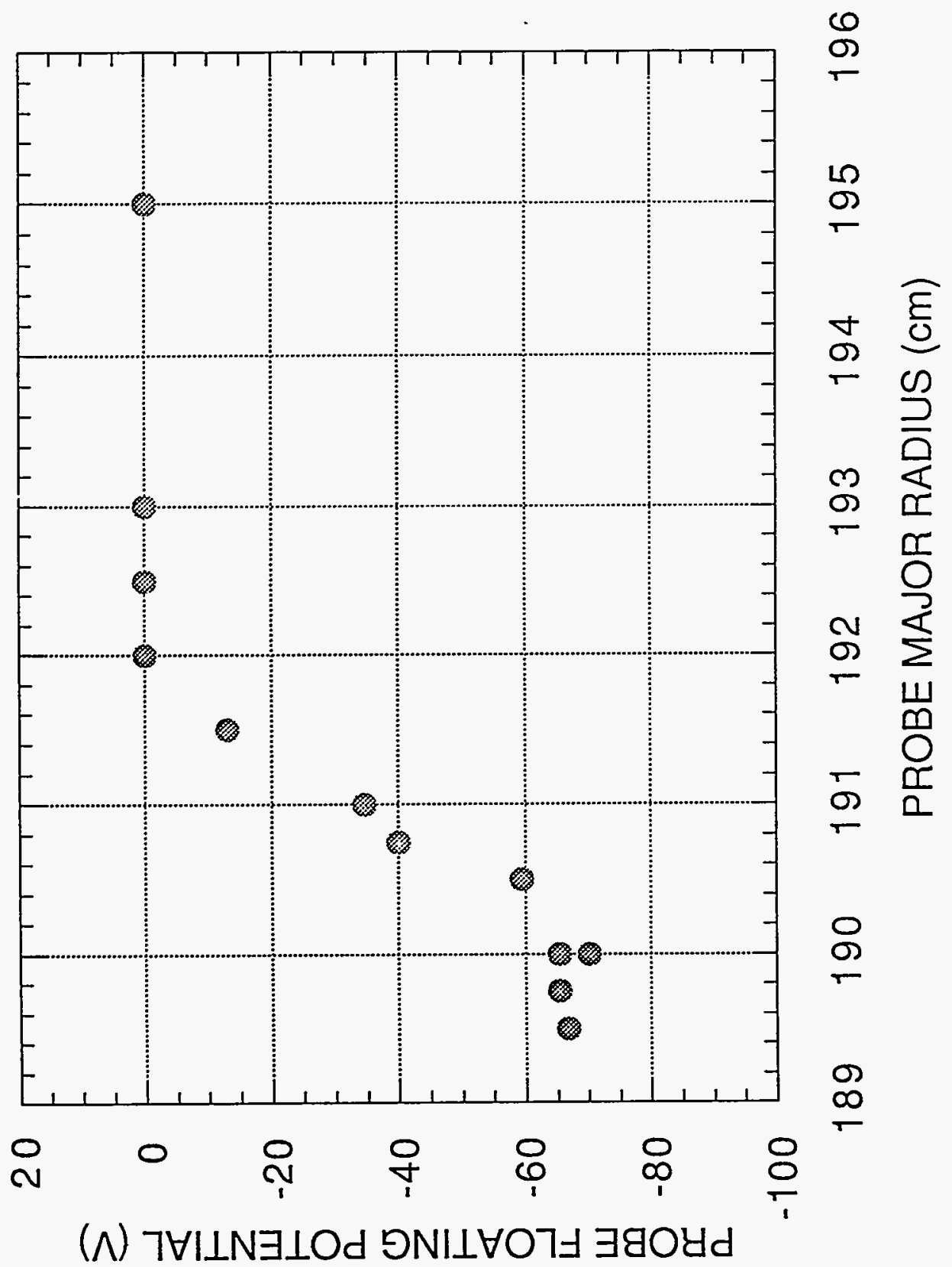




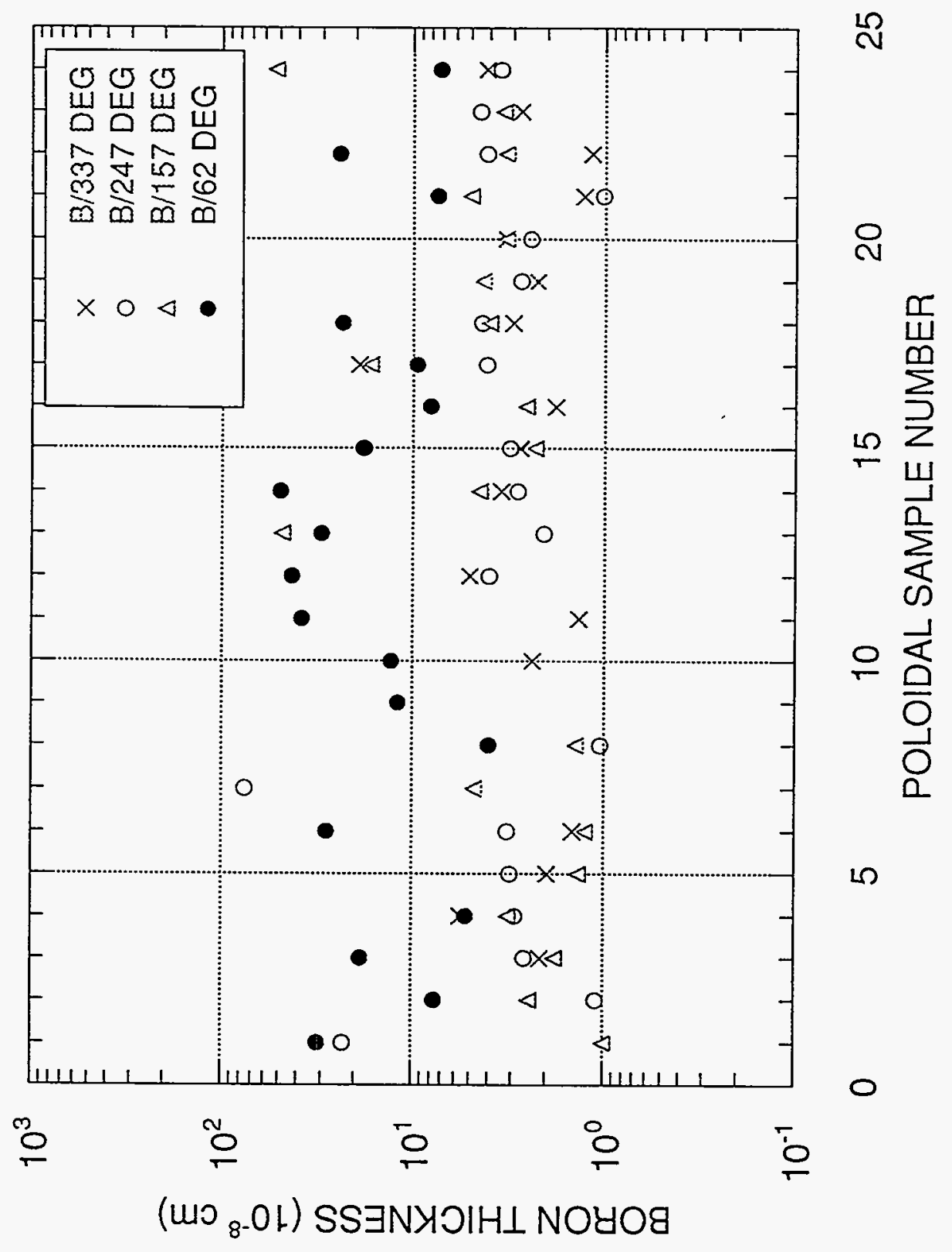




\section{EXTERNAL DISTRIBUTION IN ADDITION TO UC-420}

Dr. F. Paoloni, Univ. of Wollongong, AUSTRALIA

Prof. R.C. Cross, Univ. of Sydney, AUSTRALIA

Plasma Research Lab., Australian Nat. Univ., AUSTRALIA

Prof. I.R. Jones, Flinders Univ, AUSTRALIA

Prof. F. Cap, Inst. for Theoretical Physics, AUSTRIA

Prof. M. Heindler, Institut für Theoretische Physik, AUSTRIA

Prof. M. Goossens, Astronomisch Instituut, BELGIUM

Ecole Royale Militaire, Lab. de Phy. Plasmas, BELGIUM

Commission-European, DG. XII-Fusion Prog., BELGIUM

Prof. R. Bouciqué, Rijksuniversiteit Gent, BELGIUM

Dr. P.H. Sakanaka, Instituto Fisica, BRAZIL

Prof. Dr. I.C. Nascimento, Instituto Fisica, Sao Paulo, BRAZIL Instituto Nacional De Pesquisas Espaciais-INPE, BRAZIL. Documents Otfice, Atomic Energy of Canada Ltd., CANADA Ms. M. Morin, CCFWTokamak de Varennes, CANADA Dr. M.P. Bachynski, MPB Technologies, Inc., CANADA

Dr. H.M. Skarsgard, Univ. of Saskatchewan, CANADA

Prof. J. Teichmann, Univ. of Montreal, CANADA

Prof. S.R. Sreenivasan, Univ. of Calgary, CANADA

Prof. R. Marchand, INRS-Energie et Materiaux, CANADA

Dr. R. Bolton, Centre canadien de fusion magnétique, CANADA

Dr. C.R. James, Univ. of Alberta, CANADA

Dr. P. Lukác, Komenského Universzita, CZECHO-SLOVAKIA

The Librarian, Culham Laboratory, ENGLAND

Library, R61, Rutherford Appleton Laboratory, ENGLAND

Mrs. S.A. Hutchinson, JET Library, ENGLAND

Dr. S.C. Sharma, Univ. of South Pacific, FIJI ISLANDS

P. Măhönen, Univ. of Helsinki, FINLAND

Prof. M.N. Bussac, Ecole Polytechnique, FRANCE

C. Mouttet, Lab. de Physique des Milieux lonisés, FRANCE

J. Radet, CEN/CADARACHE - Bat 506, FRANCE

Prof. E. Economou, Univ. of Crete, GREECE

Ms. C. Rinni, Univ. of loannina, GREECE

Preprint Library, Hungarian Academy of Sci., HUNGARY

Dr. B. DasGupta, Saha Inst. of Nuclear Physics, INDIA

Dr. P. Kaw, Inst. for Plasma Research, INDIA

Dr. P. Rosenau, Israel Inst. of Technology, ISRAEL

Librarian, Intemational Center for Theo Physics, ITALY

Miss C. De Palo, Associazione EURATOM-ENEA , ITALY

Dr. G. Grosso, Istituto di Fisica del Plasma, ITALY

Prof. G. Rostangni, Istituto Gas lonizzati Del Cnr, ITALY
Dr. H. Yamato, Toshiba Res \& Devel Center, JAPAN

Prof. I. Kawakami, Hiroshima Univ., JAPAN

Prof. K. Nishikawa, Hiroshima Univ., JAPAN

Librarian, Naka Fusion Research Establishment, JAERI, JAPAN

Director, Japan Atomic Energy Research Inst., JAPAN

Prof. S. Itoh, Kyushu Univ., JAPAN

Research Info. Ctr., National Instit. for Fusion Science, JAPAN

Prof. S. Tanaka, Kyoto Univ., JAPAN

Library, Kyoto Univ., JAPAN

Prof. N. Inoue, Univ. of Tokyo, JAPAN

Secretary, Plasma Section, Electrotectnical Lab., JAPAN

Dr. O. Mitarai, Kumamoto Inst. of Technology, JAPAN

Dr. G.S. Lee, Korea Basic Sci. Ctr., KOREA

J. Hyeon-Sook, Korea Atomic Energy Research Inst., KOREA

D.I. Choi, The Korea Adv. Inst. of Sci. \& Tech., KOREA

Prof. B.S. Liley, Univ. of Waikato, NEW ZEALAND

Inst of Physics, Chinese Acad Sci PEOPLE'S REP. OF CHINA

Library, Inst. of Plasma Physics, PEOPLE'S REP. OF CHINA

Tsinghua Univ. Library, PEOPLE'S REPUBLIC OF CHINA

Z. Li. S.W. Inst Physics, PEOPLE'S REPUBLIC OF CHINA

Prof. J.A.C. Cabral, Instituto Superior Tecnico, PORTUGAL

Prof. M.A. Hellberg, Univ. of Natal, S. AFRICA

Prof. D.E. Kim, Pohang Inst. of Sci. \& Tech., SO. KOREA

Prof. C.I.E.M.A.T, Fusion Division Library, SPAIN

Dr. L. Stenflo, Univ. of UMEA, SWEDEN

Library, Royal Inst. of Technology, SWEDEN

Prof. H. Wilhelmson, Chalmers Univ. of Toch., SWEDEN

Centre Phys. Des Plasmas, Ecole Polytech, SWITZERLAND

Bibliotheek, Inst. Voor Plasma-Fysica, THE NETHERLANDS

Asst. Prof. Dr. S. Cakir, Middle East Tech. Univ., TURKEY

Dr. V.A. Glukhikh,Sci. Res. Inst. Electrophys.I Apparatus, USSR

Dr. D.D. Ryutov, Siberian Branch of Academy of Sci., USSR

Dr. G.A. Eliseev, I.V. Kurchatov Inst., USSR

Librarian, The Ukr.SSR Academy of Sciences, USSR

Dr. L.M. Kovrizhnykh, Inst. of General Physics, USSR

Kernforschungsanlage GmbH, Zentralbibliothek, W. GERMANY

Bibliothek, Inst. Für Plasmaforschung, W. GERMANY

Prof. K. Schindler, Ruhr-Universitát Bochum, W. GERMANY

Dr. F. Wagner, (ASDEX), Max-Planck-Institut, W. GERMANY

Librarian, Max-Planck-Institut, W. GERMANY 